\title{
A Useful Stone Fragments and Dust Extraction Method during Percutaneous Nephrolithotomy; Suction Technique
}

\author{
Bulent Kati* \\ Department of Urology, Faculty of Medicine, Harran University, Turkey
}

Submission: March 08, 2017; Published: April 17, 2017

*Corresponding author: Bulent Kati, Department of Urology, Faculty of Medicine, Harran University, Turkey, Email: bulentkati@yahoo.com

\begin{abstract}
Percutaneous nephrolithotomy (PCNL) is widely used for large kidney stones nowadays in many clinics. It is an important minimally invasive surgical procedure with great success and low complication rates. In order to remove large kidney stones, it is first necessary to break the stones with any lithotripter. In this case, it reveals difficult stone fragments and dust to extraction. In this article, we present a useful method to remove stone fragments, dust and blood clots which are difficult to remove easily and simply.
\end{abstract}

Keywords: Percutaneous nephrolithotomy; Kidney stones; Nasogastric tube

\section{Introduction}

Percutaneous nephrolithotomy (PCNL) plays a main role in managing large $(>2 \mathrm{~cm})$ renal stones [1]. The main goal of PCNL and other surgical interventions for urolithiasis is complete stone removal to achieve a stone-free status. Any residual stone fragments following surgery impair the success of the operation. After kidney stones are broken, small amounts of residues and dust are distributed to the kidney system and this depending on the structure of the stone. Thus, remaining remnant particles, dust or residual fragments may cause flank pain, urinary tract infection, and acute urinary obstructions [2]. Bleedings during renal dilation can disrupt the quality of the nephroscope visualizing system and the concealment of the stone causing blood clots. It is both time consuming and difficult to remove the blood clots and the stone dusts with forceps. For this reason, we used the suction technique, which is a very useful and inexpensive method to reduce such situations during the PCNL and to leave a minimal stone fragments and dust behind.

\section{Surgical Technique}

We applied our own suction technique in which a $16 \mathrm{~F}$ Nasogastric tube (NGT) was combined with a sponge at the head of the aspirator arm (Figure 1). The cut end of the NGT (cut nearly $1 \mathrm{~cm}$ for full open entrance) was sent through the renal sheath and then it pulled on the stone fragments or dust collected them into the sponge at the tip with negative pressure created by the aspirator. The saline should be sent through the renal sheath with a nephroscope during aspiration. Sometimes stone fragments were stuck in the NGT; however, these were pushed out with a pneumatic lithotripter stick. Suction is done by gently touching the NGT in the renal sheath with a few touches until the end. As the NGT catheter is removed from the renal sheath, it is slowly withdrawn so that larger stones can be removed with NGT's tip with negative pressure effect. After each application, the assistant separates the absorbed stone fragments, dusts and blood clots by controlling the sponge between the aspirator tube at the top of the NGT (Figure 2).

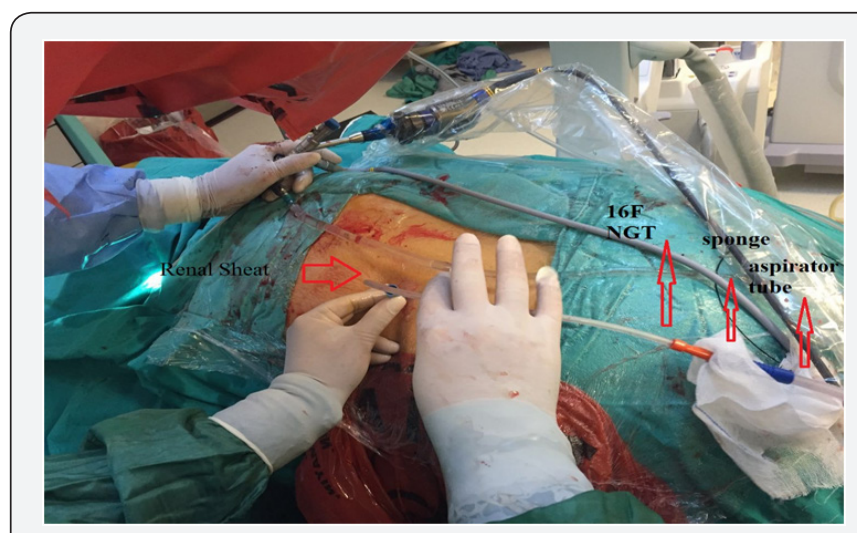

Figure 1: Application of aspiration system during operation. 


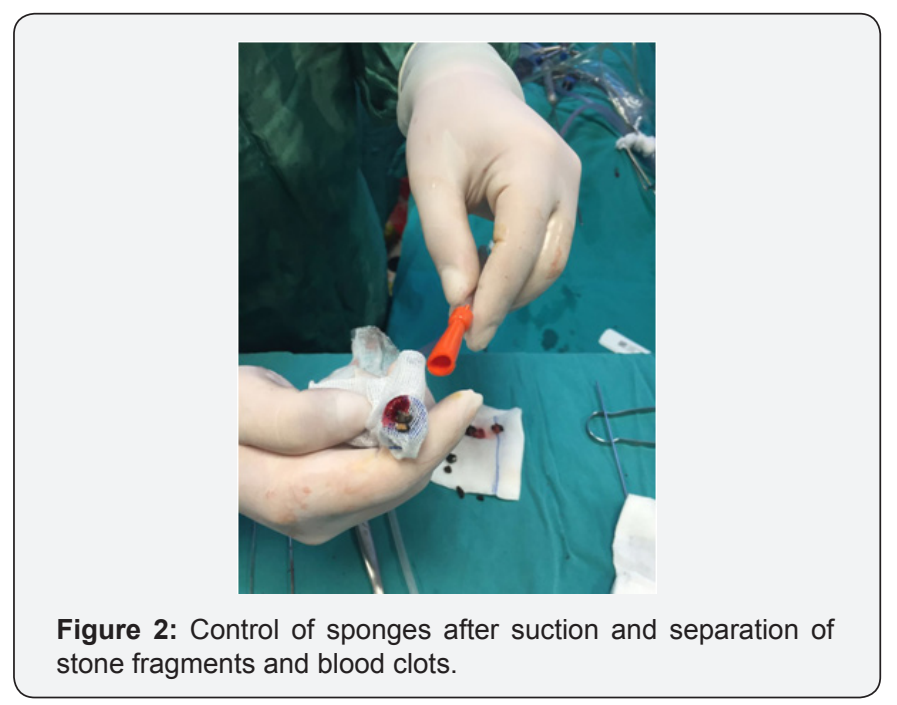

\section{Comments}

During the PCNL operation, the dusts formed after the stones were broken by pneumatic or ultrasonic lithotripter and the blood clots in the system destroyed the vision and made the operation difficult. There are many studies in the literature for the collection of these stone fragments and dusts, many of which are expensive and in-vitro techniques [3,4]. A technique described by Panah et al. [5] is similar to our technique, but using $14 \mathrm{~F} \mathrm{NGT}$ with a 50cc syringe, irrigating through the renal sheath and removing the stone fragments by overflowing the saline from renal sheath. In this technique, fragments within the renal sheath can be removed, while other fragments and dusts around the renal sheath can escape from other segments of the kidney even into the ureter and are more difficult to apply because they require constant pressure irrigation. In our technique, all fragments, dusts, and blood clots that can pass through $16 \mathrm{~F}$ NGT under negative pressure and accumulate at the sponge end. Thus, a quicker and more effective collection is achieved. We performed more than 50 PCNL operations in our clinic with this method and we observed that the postoperative fewer residual stone fragments with dust and blood clots in patients. Thus, after removal of the nephrostomy, residual colic pain, urine leakage from the nephrostomy tract and other similar complaints remaining in the patients were less frequent. We think that this cheap and effective method can be easily used in every clinic.

\section{References}

1. Ramakumar S, Segura JW (2000) Renal calculi. Percutaneous management. Urol Clin North Am 27(4): 617-622.

2. Türk CK, Petrik T, Sarica A, Seitz C, Skolarikos A, et al. (2015) EAU guidelines on interventional treatment for urolithiasis. Eur Urol 2838(15): 00700-00709.

3. Mager R, Balzereit C, Hüsch T, Herrmann T, Nicklas A, et al. (2016) Clearance of stone fragments and stone dust by continuous flow hydrodynamics in percutaneous renal surgery: an in-vitro study. J Endourol 30(4): 441-446.

4. Antonelli JA, Beardsley H, Faddegon S, Morgan MS, Gahan JC, et al. (2016) A novel device to prevent stone fragment migration during percutaneous lithotripsy: results from an in-vitro kidney model. J Endourol 30(11): 1239-1243.

5. Panah A, Masood J, Zaman F, Papatsoris AG, El-Husseiny T, et al. (2009) A technique to flush out renal stone fragments during percutaneous nephrolithotomy. J Endourol 23(1): 5-6.

\section{Your next submission with Juniper Publishers will reach you the below assets}

- Quality Editorial service

- Swift Peer Review

- Reprints availability

- E-prints Service

- Manuscript Podcast for convenient understanding

- Global attainment for your research

- Manuscript accessibility in different formats

( Pdf, E-pub, Full Text, Audio)

- Unceasing customer service

Track the below URL for one-step submission https://juniperpublishers.com/online-submission.php 